\title{
Construction of Theoretical Capital Progress Curve Model of Power Grid Infrastructure Project Based on Contract Payment Terms
}

\author{
Junyi Yang ${ }^{1}$, Fuchang Yue ${ }^{2}$, Qian $\mathrm{Gao}^{1}$, Shijie $\mathrm{Xu}^{2}$, Yu Hong ${ }^{1, *}$, Lixin Wang ${ }^{3}, \mathrm{Jie} \mathrm{Tang}^{4}$ \\ ${ }^{1}$ Development Planning Department, State Grid Jiangsu Electric Power Company, Nanjing, Jiangsu Province \\ ${ }^{2}$ Development Planning Department, State Grid Lianyungang Power Supply Company, Lianyungang, Jiangsu Province \\ ${ }^{3}$ Material Department, State Grid Lianyungang Power Supply Company, Lianyungang, Jiangsu Province \\ ${ }^{4}$ Development Planning Department, State Grid Taizhou Power Supply Company, Taizhou, Jiangsu Province
}

\begin{abstract}
In order to implement the central government's major deployment of preventing and punishing statistical falsification, improving the authenticity of statistical data, and further improving the science and accuracy of power grid project funding forecasts. By studying the fund payment law of power grid infrastructure project and constructing the theoretical capital progress curve model of power grid infrastructure project, the progress and time point of fund payment in each link of the whole process of the project can be effectively controlled. Scientific prediction of the project life cycle at all stages of the fund demand, financing arrangements and payment control to provide a reference.
\end{abstract}

\section{Introduction}

The fund payment of power grid infrastructure project is based on the signing of the contract. According to payment terms of the contract, combined with the project construction progress and cost entry, it reflects the actual tax inclusive capital flow paid by the project to the construction party, suppliers and other relevant units. In order to further strengthen the lean management of unit infrastructure project funds, based on the payment terms of materials and service contracts, the theoretical capital progress curve model of $35 \mathrm{kV}$ and above power grid infrastructure projects is established to realize the fund prediction of the whole life cycle of the project, and provide sufficient basis for medium and long-term financing plan arrangement, so as to assist the company's investment and financing decisions, coordinate the company's fund arrangement and improve the fund efficiency and effectiveness.

\section{Relationship among power grid construction, cost and capital}

The construction progress of power grid project is the core management index of construction department, which reflects the actual construction progress of the project, and is the completion of the quantities of each sub part of the project expressed by the percentage of completion. The entry cost is the core index of project management of financial department, which reflects the actual financial expenditure of various construction costs of the project on the basis of signing the contract.

The fund payment is carried out according to the project construction, cost entry and contract payment conditions. By combing the relationship among construction, cost and capital, the formation conditions and process of project fund payment are straightened out, and the relationship between cost and fund is refined.

The contract types are divided into service type and material type. The material contract payment is generally divided into advance payment, arrival payment, operation payment and quality assurance deposit. The flow chart of the relationship between material contract fund payment and material cost entry is as follows: 


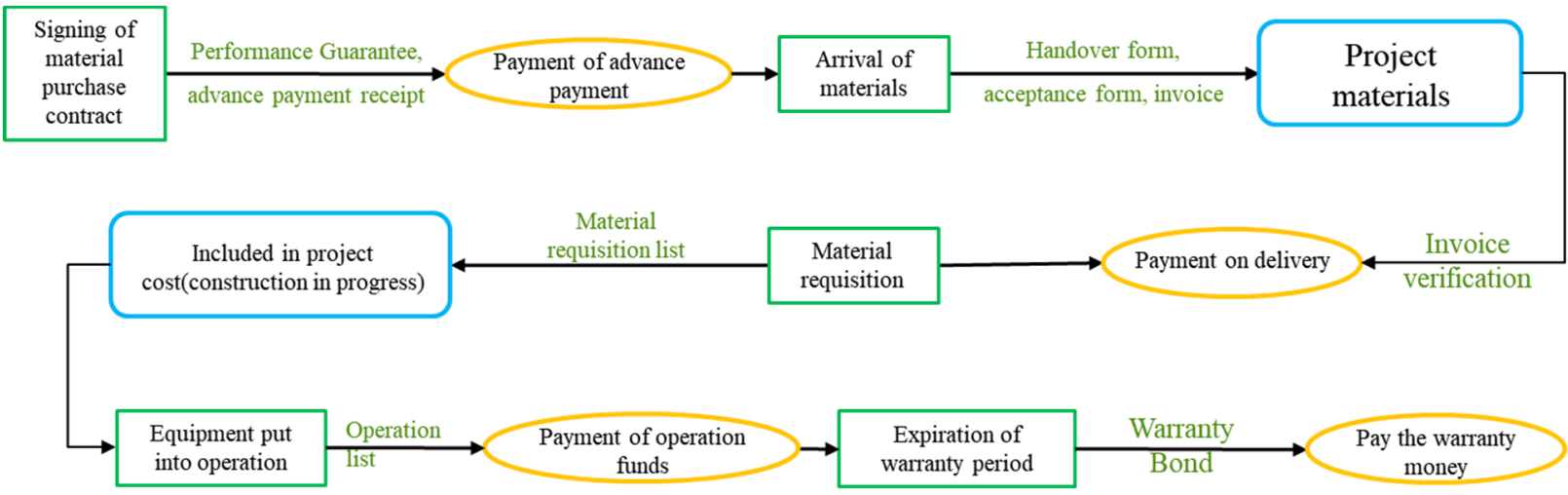

Figure 1. Flow Chart of Relationship Between Material Engineering Cost and Fund Payment

The payment of service contract is generally divided into advance payment, progress payment, settlement payment and quality assurance deposit. The flow chart of the relationship between fund payment and service cost entry of service contract (taking engineering construction contract as an example) is as follows:

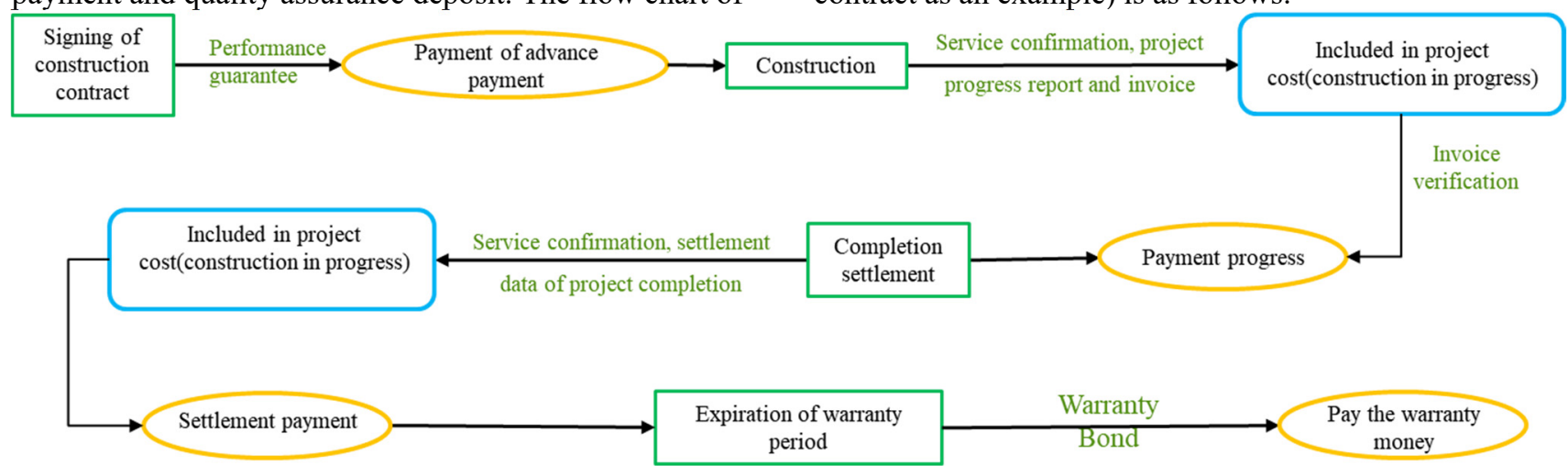

Figure 2. Flow Chart of Relationship Between Service Engineering Cost and Fund Payment

\section{Construct the theoretical capital progress curve model}

Based on the WBS element of the project, through combing the business logic among the construction progress, project cost and fund payment, the theoretical capital progress curve model of power grid infrastructure project is constructed based on project budget estimate, milestone plan and contract payment terms. Forecast the monthly fund payment from the beginning of the project into the plan to the end of the quality assurance period, draw the theoretical capital progress curve of the project, and realize the multi-dimensional prediction of the power grid project funds according to the long-term, annual and monthly.

\subsection{Sorting out the fund payment rules stipulated in the contract}

Project fund payment is based on the payment terms stipulated in the project contract. The payment terms of material contract determine the fund payment rules of equipment purchase cost and installation material cost.
The service contract corresponds to the construction engineering cost, installation cost, survey and design fee, engineering supervision cost, etc. in addition to equipment purchase and installation material cost. It mainly includes design, construction, supervision, installation and commissioning, technical service consultation, land acquisition compensation, etc.

By combing the payment rules of service contract and material contract, two important factors of fund forecast are determined: payment time point and proportion.

\subsubsection{Payment rules of material contract}

At present, State Grid Corporation of China adopts different forms of material procurement according to different voltage levels and material types. The organization forms of material procurement are divided into agreement inventory and batch purchase. Through investigation, it is known that batch procurement is often used in material procurement of projects with voltage level above $35 \mathrm{kV}$. The corresponding payment proportion of different material types and contract amount purchased in batches is shown in Table I. 
TABle I. Payment Proportion Stipulated in Different Batch Purchase Contracts

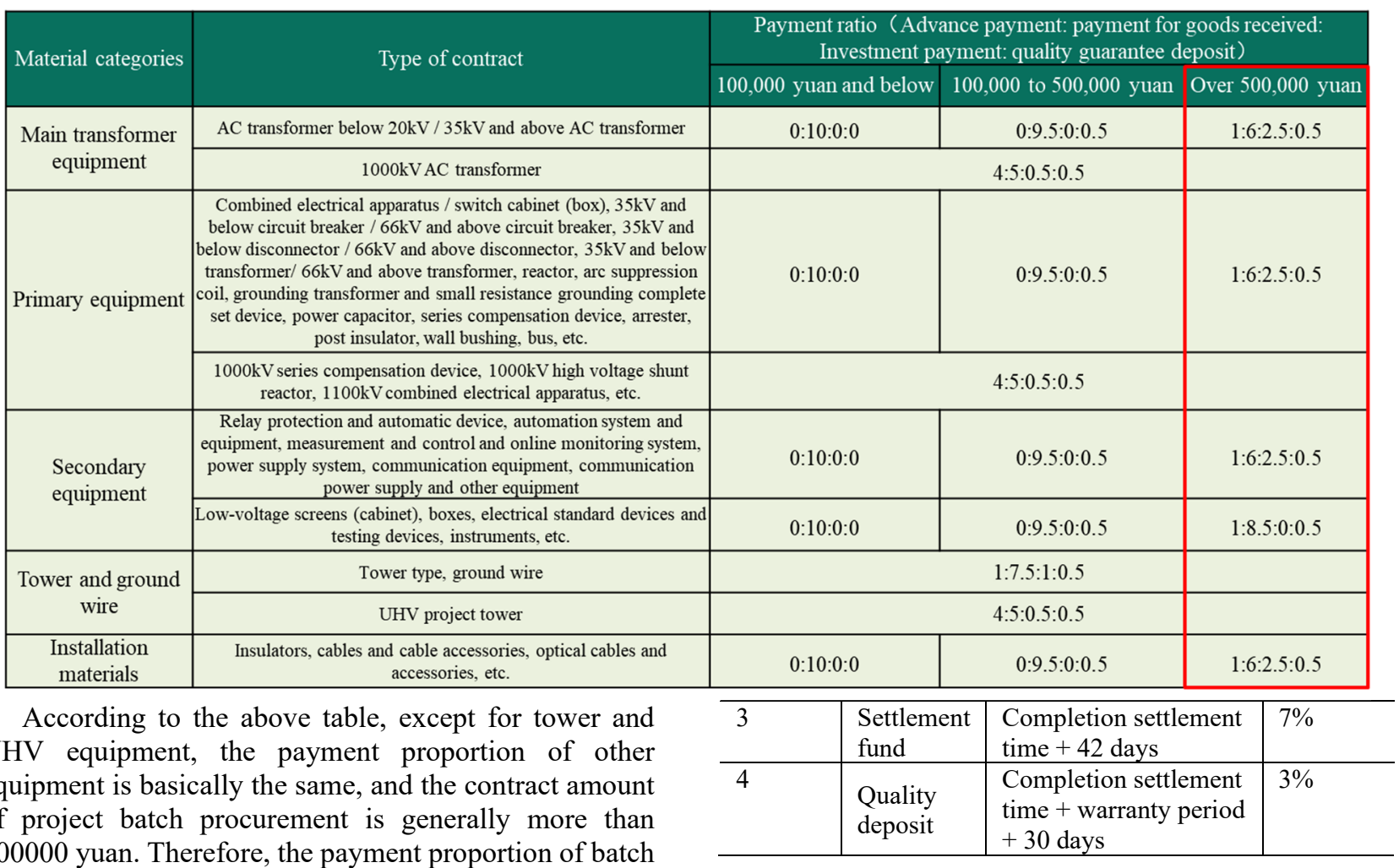
procurement materials for substation project and uniformly adopted as 1:6:2.5:0.5.

\subsubsection{Payment rules of service contract}

Service contracts correspond to construction engineering fees, installation fees, survey and design fees, and engineering supervision fees other than equipment purchase and installation material fees. Sort out the payment terms of various service contracts, and sort out the payment time and payment proportion according to the contract payment terms, as follows:

\subsubsection{Payment terms and time of construction contract}

The engineering construction contract corresponds to the engineering construction cost and installation engineering cost. By combing the payment terms of the engineering construction contract, we can get the payment time and proportion of the construction cost and installation engineering cost in each stage, as shown in Table II.

TABLE II. PAYMENT TIME AND PAYMENT PROPORTION Stipulated in the Project CONSTRUCTION CONTRACT

\begin{tabular}{l|l|l|l}
\hline $\begin{array}{l}\text { Serial } \\
\text { number }\end{array}$ & Money & $\begin{array}{l}\text { Time of payment } \\
\text { stipulated in the } \\
\text { contract }\end{array}$ & $\begin{array}{l}\text { Payment } \\
\text { ratio }\end{array}$ \\
\hline 1 & $\begin{array}{l}\text { Advance } \\
\text { payment }\end{array}$ & $\begin{array}{l}\text { Contract signing time } \\
+30 \text { days }\end{array}$ & $20 \%$ \\
\hline 2 & $\begin{array}{l}\text { Progress } \\
\text { payment }\end{array}$ & $\begin{array}{l}\text { Time for issuing } \\
\text { progress payment } \\
\text { certificate + 28 days }\end{array}$ & $70 \%$ \\
\hline
\end{tabular}

\subsubsection{Land compensation agreement and policy treatment agreement}

The land use compensation agreement and policy treatment agreement correspond to the land acquisition and clearance fee. Through the payment terms of the land use compensation agreement and policy treatment agreement, the payment time and payment proportion of land acquisition and clearing fee, as shown in Table III.

TABLE III. PAYMENT TIME AND PAYMENT PROPORTION STIPULATED IN LAND USE COMPENSATION AGREEMENT AND Policy TREATMENT AgReEMENT

\begin{tabular}{l|l|l|l}
\hline $\begin{array}{l}\text { Serial } \\
\text { number }\end{array}$ & Money & $\begin{array}{l}\text { Time of payment } \\
\text { stipulated in the } \\
\text { contract }\end{array}$ & $\begin{array}{l}\text { Payment } \\
\text { ratio }\end{array}$ \\
\hline 1 & $\begin{array}{l}\text { Land } \\
\text { acquisition } \\
\text { and } \\
\text { clearance fee }\end{array}$ & $\begin{array}{l}\text { Contract signing } \\
\text { time }+30 \text { days }\end{array}$ & $100 \%$ \\
\hline
\end{tabular}

\subsubsection{Preliminary work cost contract}

Through sorting out the preliminary work cost contracts such as geological hazard risk assessment and feasibility study commission contract, we can get the payment time and payment proportion of the project preliminary work cost, as shown in Table IV. 
TABLE IV. PAYMENT TIME AND PAYMENT PROPORTION AgreEd IN THE CONTRACT OF PROJECT PRELIMINARY WORK Cost

\begin{tabular}{l|l|l|l}
\hline $\begin{array}{l}\text { Serial } \\
\text { number }\end{array}$ & Money & $\begin{array}{l}\text { Time of } \\
\text { payment } \\
\text { stipulated in } \\
\text { the contract }\end{array}$ & $\begin{array}{l}\text { Payment } \\
\text { ratio }\end{array}$ \\
\hline 1 & $\begin{array}{l}\text { Preliminary } \\
\text { work cost } \\
\text { of the } \\
\text { project }\end{array}$ & $\begin{array}{l}\text { Contract signing } \\
\text { time }+30 \text { days }\end{array}$ & $100 \%$ \\
\hline
\end{tabular}

\subsubsection{Contract for prospecting and designing}

By combing the payment terms of survey and design contract, we can get the payment time and proportion of survey and design fee in each stage, as shown in Table V.

TABLE V. PAYMENT TIME AND PAYMENT PROPORTION AGREED IN THE SURVEY AND DESIGN CONTRACT

\begin{tabular}{l|l|l|l}
\hline $\begin{array}{l}\text { Serial } \\
\text { number }\end{array}$ & Money & $\begin{array}{l}\text { Time of payment } \\
\text { stipulated in the } \\
\text { contract }\end{array}$ & $\begin{array}{l}\text { Payment } \\
\text { ratio }\end{array}$ \\
\hline 1 & $\begin{array}{l}\text { Advance } \\
\text { payment }\end{array}$ & $\begin{array}{l}\text { Contract signing time } \\
+30 \text { days }\end{array}$ & $30 \%$ \\
\hline 2 & $\begin{array}{l}\text { Progress } \\
\text { payment }\end{array}$ & $\begin{array}{l}\text { Time to submit } \\
\text { complete set of } \\
\text { drawings + 30 days }\end{array}$ & $40 \%$ \\
\hline 3 & $\begin{array}{l}\text { Settlement } \\
\text { fund }\end{array}$ & $\begin{array}{l}\text { Completion settlement } \\
\text { time + 42 days }\end{array}$ & $27 \%$ \\
\hline 4 & $\begin{array}{l}\text { Quality } \\
\text { deposit }\end{array}$ & $\begin{array}{l}\text { Operation time }+ \\
\text { warranty period }(1 \\
\text { year) }+30 \text { days }\end{array}$ & $3 \%$ \\
\hline
\end{tabular}

\subsubsection{Project supervision contract}

By combing the payment terms of the project supervision contract, we can get the payment time and proportion of the project supervision fee in each stage, as shown in Table VI.
TABLE VI. PAyment Time AND PAyMENT PROPORTION AgreEd In the ProJeCt SUPERVISION CONTRACT

\begin{tabular}{l|l|l|l}
\hline $\begin{array}{l}\text { Serial } \\
\text { number }\end{array}$ & Money & $\begin{array}{l}\text { Time of payment } \\
\text { stipulated in the } \\
\text { contract }\end{array}$ & $\begin{array}{l}\text { Payment } \\
\text { ratio }\end{array}$ \\
\hline 1 & $\begin{array}{l}\text { Advance } \\
\text { payment }\end{array}$ & $\begin{array}{l}\text { Contract signing time } \\
+30 \text { days }\end{array}$ & $20 \%$ \\
\hline 2 & $\begin{array}{l}\text { The time point of } \\
\text { project quantity } \\
\text { (investment amount) } \geq \\
50 \%+30 \text { days; } \\
\text { payment } \\
\text { operation time }+30 \\
\text { days }\end{array}$ & $\begin{array}{l}30 \% ; \\
40 \%\end{array}$ \\
\hline 4 & $\begin{array}{l}\text { Settlement } \\
\text { fund }\end{array}$ & $\begin{array}{l}\text { Completion settlement } \\
\text { time }+15 \text { days }\end{array}$ & $7 \%$ \\
\hline & Quality & $\begin{array}{l}\text { Operation time }+ \\
\text { warranty period }+30 \\
\text { days }\end{array}$ & $3 \%$ \\
\hline
\end{tabular}

\subsubsection{Loan contract}

General loan contract for interest payment requirements: from the interest date, pay interest every March, June, September, December.

\subsubsection{Other}

Other expenses include: design document review fee, project legal person management fee, bidding fee, production preparation fee, project settlement audit fee, etc. This item includes many expenses, but the amount is small. According to the fund payment experience, the average apportionment payment in the process of project construction is adopted.

\subsection{Prediction of fund payment time point combined with milestone node in engineering construction}

By combing the payment terms of service and material contracts, the contract agreed payment time and proportion of various expenses are determined. Combined with the milestone node of project construction, the fund payment time point of various expenses in the whole process of the project is determined. The predicted payment time of various expenses is shown in Table VII.

TABle ViI. Prediction of Payment Time of Various Expenses (With Milestone Time Point of Project Construction Milestone CONSTRUCTION)

\begin{tabular}{l|l|l}
\hline Money & Time of payment stipulated in the contract & \multicolumn{1}{l}{$\begin{array}{l}\text { The forecast time of fund payment at milestone } \\
\text { nodes of construction }\end{array}$} \\
\hline \begin{tabular}{l} 
1、 Equipment purchase cost: material contract \\
\hline $\begin{array}{l}\text { Advance } \\
\text { payment }\end{array}$
\end{tabular} & Contract signing time +60 days & $\begin{array}{l}\text { Expected opening time of materials }+\mathbf{3 0} \text { days }+ \\
60 \text { days }\end{array}$ \\
\hline $\begin{array}{l}\text { Arrival } \\
\text { payment }\end{array}$ & Arrival time $+\mathbf{6 0}$ days & $\begin{array}{l}\text { Equipment installation start time }-\mathbf{6 0} \text { days }+60 \\
\text { days }\end{array}$ \\
\hline $\begin{array}{l}\text { Operational } \\
\text { payment }\end{array}$ & Equipment operation time +60 days & Commissioning time +60 days \\
\hline $\begin{array}{l}\text { Quality } \\
\text { deposit }\end{array}$ & $\begin{array}{l}\text { Equipment operation time }+ \text { warranty period } \\
+60 \text { days }\end{array}$ & Production time + warranty period +60 days \\
\hline 2、Construction cost and installation cost: engineering construction contract \\
\hline
\end{tabular}




\begin{tabular}{|c|c|c|}
\hline Money & Time of payment stipulated in the contract & $\begin{array}{l}\text { The forecast time of fund payment at milestone } \\
\text { nodes of construction }\end{array}$ \\
\hline $\begin{array}{l}\text { Advance } \\
\text { payment }\end{array}$ & Contract signing time +30 days & $\begin{array}{l}\text { Estimated time of bid opening for construction } \\
\text { bidding }+\mathbf{3 0} \text { days }+30 \text { days }\end{array}$ \\
\hline $\begin{array}{l}\text { Progress } \\
\text { payment }\end{array}$ & $\begin{array}{l}\text { Time for issuing progress payment certificate } \\
+28 \text { days }\end{array}$ & Cost entry time +28 days \\
\hline $\begin{array}{l}\text { Settlement } \\
\text { fund }\end{array}$ & Completion settlement time +42 days & Completion settlement approval time +42 days \\
\hline $\begin{array}{l}\text { Quality } \\
\text { deposit }\end{array}$ & $\begin{array}{l}\text { Completion settlement time }+ \text { warranty } \\
\text { period }+30 \text { days }\end{array}$ & $\begin{array}{l}\text { Completion settlement approval time }+ \\
\text { warranty period }+30 \text { days }\end{array}$ \\
\hline \multicolumn{3}{|c|}{ 3、Other expenses } \\
\hline \multicolumn{3}{|c|}{$\begin{array}{l}\text { 3.1 Construction site requisition and clearance fee: land compensation agreement or policy treatment } \\
\text { agreement }\end{array}$} \\
\hline $\begin{array}{l}\text { Settlement } \\
\text { fund }\end{array}$ & Contract signing time +30 days & $\begin{array}{l}\text { Substation four links and one leveling / line } \\
\text { retest completion time }+30 \text { days }\end{array}$ \\
\hline \multicolumn{3}{|c|}{ 3.2 Project supervision fee: project supervision contract } \\
\hline $\begin{array}{l}\text { Advance } \\
\text { payment }\end{array}$ & Contract signing time +30 days & $\begin{array}{l}\text { Estimated time of bid opening for construction } \\
\text { bidding }+30 \text { days }\end{array}$ \\
\hline $\begin{array}{l}\text { Progress } \\
\text { payment }\end{array}$ & $\begin{array}{l}\text { The time point of project quantity } \\
\text { (investment amount) } \geq \mathbf{5 0 \%}+30 \text { days; } \\
\text { Operation time }+30 \text { days }\end{array}$ & $\begin{array}{l}\text { The time point of recording progress } \geq \mathbf{5 0 \%}+ \\
30 \text { days; } \\
\text { Commissioning time }+30 \text { days }\end{array}$ \\
\hline $\begin{array}{l}\text { Settlement } \\
\text { fund }\end{array}$ & Completion settlement time +15 days & Completion settlement approval time +15 days \\
\hline $\begin{array}{l}\text { Quality } \\
\text { deposit }\end{array}$ & Operation time + warranty period +30 days & $\begin{array}{l}\text { Commissioning time }+ \text { warranty period }+30 \\
\text { days }\end{array}$ \\
\hline \multicolumn{3}{|c|}{$\begin{array}{l}\text { 3.3 Preliminary work cost of the project: geological hazard risk assessment, feasibility study commission } \\
\text { contract, etc }\end{array}$} \\
\hline $\begin{array}{l}\text { Settlement } \\
\text { fund }\end{array}$ & Contract signing time +30 days & Preliminary design review time +30 days \\
\hline \multicolumn{3}{|c|}{ 3.4 Survey and design fee: Survey and design contract } \\
\hline $\begin{array}{l}\text { Advance } \\
\text { payment }\end{array}$ & Contract signing time +30 days & Preliminary design review time +30 days \\
\hline $\begin{array}{l}\text { Progress } \\
\text { payment }\end{array}$ & $\begin{array}{l}\text { Time to submit complete set of drawings }+30 \\
\text { days }\end{array}$ & Start time +30 days \\
\hline $\begin{array}{l}\text { Settlement } \\
\text { fund }\end{array}$ & Completion settlement time +42 days & Completion settlement approval time +42 days \\
\hline $\begin{array}{l}\text { Quality } \\
\text { deposit }\end{array}$ & Operation time + warranty period +30 days & $\begin{array}{l}\text { Commissioning time }+ \text { warranty period }+30 \\
\text { days }\end{array}$ \\
\hline \multicolumn{3}{|c|}{ 3.5 Loan interest during construction period: loan contract } \\
\hline $\begin{array}{l}\text { Settlement } \\
\text { fund }\end{array}$ & $\begin{array}{l}\text { Interest is paid every March, June, September } \\
\text { and December from the interest date }\end{array}$ & $\begin{array}{l}\text { Payment at the end of each quarter during the } \\
\text { construction period }\end{array}$ \\
\hline \multicolumn{3}{|c|}{ 3.6 Others: design document review, bidding, legal person management, production preparation, etc. } \\
\hline $\begin{array}{l}\text { Settlement } \\
\text { fund }\end{array}$ & - & $\begin{array}{l}\text { Average apportionment and payment in the process } \\
\text { of project construction }\end{array}$ \\
\hline
\end{tabular}

By combing the time point and proportion of fund payment, the fund forecast allocation rules are determined. Combined with the project budget data and considering the project balance, the fund forecast expenditure amount of each month in the whole process from the early stage of the project to the completion of the quality assurance deposit payment is calculated, the fund payment progress is determined, and the theoretical fund progress curve is drawn.

\section{Model validation}

Typical power grid infrastructure projects with different voltage levels and different types are selected to calculate and draw the theoretical capital progress curve of the project, and compare with the actual capital progress curve. Taking a $220 \mathrm{kV}$ substation project as an example, a case study is carried out. The project is planned to start on August 29, 2016 and put into operation on May 28, 2018. The estimated amount of the project is 75.43 million yuan. The estimated amount of various expenses including tax is shown in Table VIII. 
Table ViII. Cost Details of Project Budget Estimate

\begin{tabular}{l|l|l|l|l}
\hline Expense item & $\begin{array}{l}\text { Construction } \\
\text { cost }\end{array}$ & $\begin{array}{l}\text { Equipment } \\
\text { purchase } \\
\text { cost }\end{array}$ & $\begin{array}{l}\text { Installation } \\
\text { cost }\end{array}$ & $\begin{array}{l}\text { Other } \\
\text { expenses }\end{array}$ \\
\hline $\begin{array}{l}\text { Estimated } \\
\text { amount } \\
\text { (10000 yuan) }\end{array}$ & 1634 & 3567 & 861 & 1481 \\
\hline
\end{tabular}

The details of other expenses are shown in Table IX.
TABLE IX. OTher Cost Details of Project Budget ESTIMATE

\begin{tabular}{|c|c|c|c|c|c|c|}
\hline $\begin{array}{l}\text { Expense } \\
\text { item }\end{array}$ & $\begin{array}{l}\text { Constructio } \\
\text { n site } \\
\text { requisition } \\
\text { and } \\
\text { cleaning fee }\end{array}$ & $\begin{array}{l}\text { Project } \\
\text { supervisio } \\
\text { n fee }\end{array}$ & $\begin{array}{l}\text { Preliminar } \\
\text { y work } \\
\text { cost of the } \\
\text { project }\end{array}$ & $\begin{array}{l}\text { Surve } \\
\text { y and } \\
\text { desig } \\
\text { n fee }\end{array}$ & \begin{tabular}{|l|} 
Interest on \\
loan \\
during \\
constructio \\
n period
\end{tabular} & $\begin{array}{l}\text { Othe } \\
\mathbf{r}\end{array}$ \\
\hline $\begin{array}{l}\text { Estimate } \\
\text { d } \\
\text { amount } \\
(10000 \\
\text { yuan) }\end{array}$ & 518 & 94 & 93 & 250 & 133 & 393 \\
\hline
\end{tabular}

The annual milestone plan and construction schedule of the project are shown in Table X.

Table $\boldsymbol{X}$. The Annual Milestone Plan and Construction Schedule of the Project

\begin{tabular}{|c|c|c|c|c|c|c|c|c|c|c|}
\hline $\begin{array}{c}\text { Milestone } \\
\text { node }\end{array}$ & $\begin{array}{c}\text { Review time } \\
\text { of } \\
\text { preliminary } \\
\text { design }\end{array}$ & $\begin{array}{c}\text { Estimated bid } \\
\text { opening time for } \\
\text { materials/expected } \\
\text { bid opening time } \\
\text { for construction } \\
\text { bidding }\end{array}$ & $\begin{array}{c}\text { Substation } \\
\text { four } \\
\text { connections } \\
\text { and one } \\
\text { leveling/line } \\
\text { retest } \\
\text { completion } \\
\text { time }\end{array}$ & $\begin{array}{l}\text { Start } \\
\text { time }\end{array}$ & $\begin{array}{c}\text { Civil } \\
\text { construction } \\
\text { completion } \\
\text { time }\end{array}$ & $\begin{array}{c}\text { Equipment } \\
\text { installation } \\
\text { completion } \\
\text { time }\end{array}$ & $\begin{array}{l}\text { Commissioning } \\
\text { completion time }\end{array}$ & $\begin{array}{c}\text { Production } \\
\text { time }\end{array}$ & $\begin{array}{c}\text { Approval } \\
\text { time of } \\
\text { completion } \\
\text { settlement }\end{array}$ & $\begin{array}{c}\text { Expiration } \\
\text { of } \\
\text { warranty } \\
\text { period }\end{array}$ \\
\hline $\begin{array}{c}\text { Planned } \\
\text { completion } \\
\text { time }\end{array}$ & $2015 / 12 / 30$ & $2016 / 3 / 10$ & $2016 / 5 / 25$ & 2016/8/29 & $2017 / 8 / 30$ & $2018 / 4 / 4$ & $2018 / 4 / 12$ & $2018 / 5 / 28$ & $2018 / 8 / 25$ & $2020 / 5 / 28$ \\
\hline
\end{tabular}

According to the project budget estimate and milestone plan, the monthly fund payment progress of the project is predicted and the theoretical fund progress curve is drawn by applying the above fund prediction rules. The accuracy of the progress curve and the actual payment curve are verified by the scientific model.

\section{Comparison of theoretical and actual capital progress curves of a project}

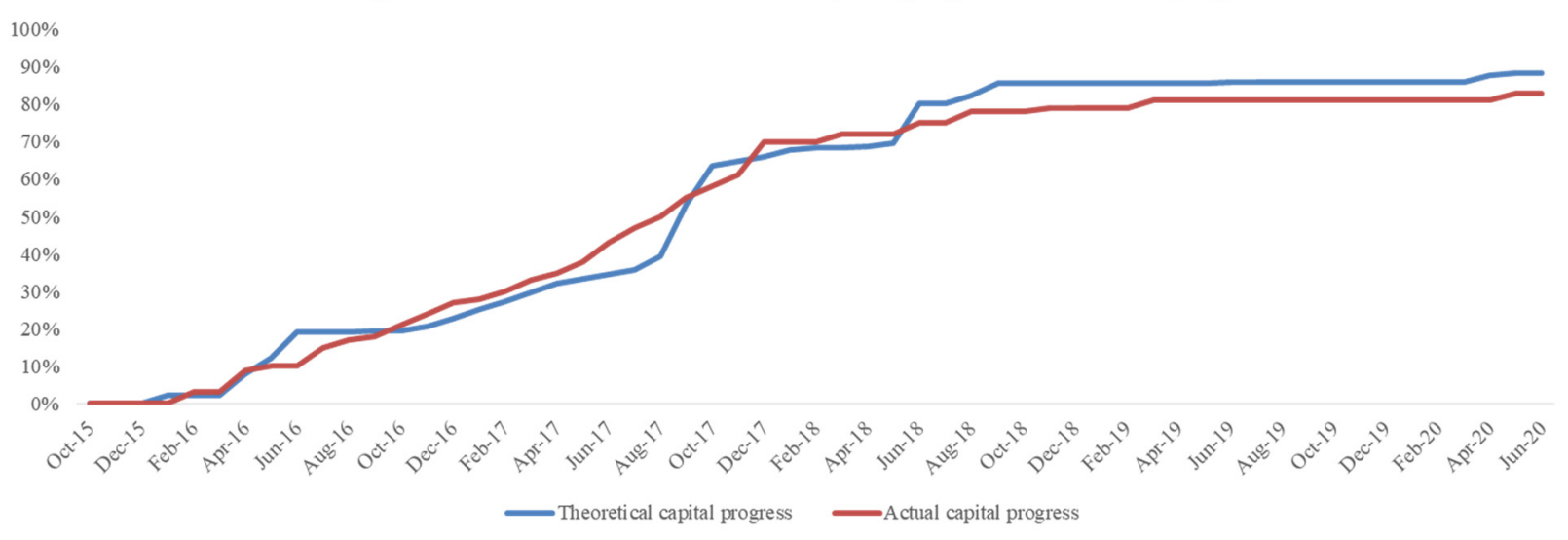

\begin{tabular}{|c|c|c|c|c|c|c|c|c|c|c|}
\hline Milestone node & $\begin{array}{c}\text { Review time } \\
\text { of preliminary } \\
\text { design }\end{array}$ & $\begin{array}{c}\text { Estimated bid opening time } \\
\text { for materials/expected bid } \\
\text { opening time for } \\
\text { construction bidding }\end{array}$ & $\begin{array}{c}\text { Substation four } \\
\text { connections and one } \\
\text { leveling/line retest } \\
\text { completion time }\end{array}$ & $\begin{array}{l}\text { Start } \\
\text { time }\end{array}$ & $\begin{array}{c}\text { Civil } \\
\text { construction } \\
\text { completion } \\
\text { time }\end{array}$ & $\begin{array}{l}\text { Equipment } \\
\text { installation } \\
\text { completion } \\
\text { time }\end{array}$ & $\begin{array}{c}\text { Commissioning } \\
\text { completion } \\
\text { time }\end{array}$ & $\begin{array}{c}\text { Production } \\
\text { time }\end{array}$ & $\begin{array}{c}\text { Approval } \\
\text { time of } \\
\text { completion } \\
\text { settlement }\end{array}$ & $\begin{array}{c}\text { Expiration } \\
\text { of warranty } \\
\text { period }\end{array}$ \\
\hline $\begin{array}{c}\text { Theoretical } \\
\text { capital progress }\end{array}$ & $0 \%$ & $2 \%$ & $12 \%$ & $19 \%$ & $39 \%$ & $68 \%$ & $69 \%$ & $70 \%$ & $82 \%$ & $88 \%$ \\
\hline $\begin{array}{c}\text { Actual capital } \\
\text { progress }\end{array}$ & $0 \%$ & $3 \%$ & $10 \%$ & $17 \%$ & $50 \%$ & $72 \%$ & $72 \%$ & $72 \%$ & $78 \%$ & $83 \%$ \\
\hline $\begin{array}{l}\text { Progress } \\
\text { deviation }\end{array}$ & $0 \%$ & $1 \%$ & $-2 \%$ & $-2 \%$ & $11 \%$ & $4 \%$ & $3 \%$ & $2 \%$ & $-4 \%$ & $-5 \%$ \\
\hline
\end{tabular}

Figure 3. Comparison of Theoretical and Actual Capital Progress Curves of a Project

It can be seen from the above figure that the trend of the fund payment progress predicted by the theory is the same as that of the actual fund payment, and the difference is small. Only in the civil engineering stage, the deviation is large. Through the analysis, it is found that some materials arrive at the civil construction stage and pay for the goods, which leads to the deviation between the actual fund payment and the theoretical prediction. At the expiration of the project warranty period, the difference between the theoretical curve and the actual curve is 
caused by the difference between the actual balance rate of the project and the theoretical balance rate. Through the model validation, the theoretical capital progress curve model can better predict the progress of power grid project fund payment.

\section{Conclusion}

Through the theoretical capital progress curve model of power grid engineering, the project can automatically prepare the whole process of power grid project fund demand forecast in the project implementation stage, assist the annual fund demand forecast, provide sufficient basis for medium and long-term financing plan arrangement, and lay a solid foundation for reasonable planning of financing strategy and optimization of financial resource allocation.

\section{Reference}

1. Wang, L. L., Research on implementation strategy of financial fine management of power grid infrastructure project, Enterprise Reform and Management, 2019, pp. 149-150.

2. Sun, L., Problems in project budget management, Accounting of Township Enterprises in China, 2019, pp. 51-52.

3. Lu, W. X., Analysis on measures to strengthen fund risk prevention and control of power grid infrastructure projects, Enterprise Reform and Management, 2020, pp. 168-169.

4. Liu, Z. G., On the implementation strategy of financial fine management of power grid infrastructure project, Times Finance, 2015, pp. 189.

5. Zhang, D., Pan, M. X., On the whole process financial management of power infrastructure project in the era of big data, Financial Supervision, 2016, pp. 95-97. 